\title{
Instagram Activation as a part of University Public Relations Social Media Orchestration
}

\author{
Maya Amalia Oesman Palapah \\ Fakultas Ilmu Komunikasi, Universitas Islam Bandung, Jl. Tamansari No. 1, Bandung, Indonesia \\ E-mail: maya.amalia@unisba.ac.id_
}

\begin{abstract}
The dissemination of information is carried out in various ways, one of them through Instagram. An Instagram account should not only be a visual performance but also a place for interaction with the public. This research aims to identify a combination of various aspects carried out in the@universitasislambandung account so that it can become an attractive presentation to create an orchestration that is pleasing to the public. The method used in this research is qualitative research. Data collection techniques were carried out by interview, observation and literature study. The results of this research indicate the initial stages of identifying aspects of social media activation in the form of engagement mode on the@universitasislambandung Instagram account with its unique users. The uniqueness can be seen from the combination of the thematic agenda with Unisba's vision and mission which is manifested in publications and interactions in the chat column, in the form of comments and direct messages. This research also produced a number of recommendations to optimize the performance of this Instagram account as a representation of the institutions on syle and delivery mode by utilizing additional features available on Instagram.
\end{abstract}

Keywords: activation, instagram, orchestration and Public Relations

\section{INTRODUCTION}

The current development of communication technology plays a role in shifting Public Relations activities. Technology has been further integrated with Public Relations activities including one that is of universities. It has then become a norm when the Public Relations Officers (PRO) of a university optimize the use of social media, particularly Instagram. "Instagram is an application that is used to take pictures, to apply filters to them, and share them with the public across other social media providers, including Instagram itself“ (Zakirah, 2018). Instagram is popular among the youth due to its information sharing features, which include pictures and videos, and based on We Are Social, Indonesia has a position as one of the world's largest Instagram users (Afrilia, 2018). However, using the application requires its own tricks. Instagram is currently used by individuals and corporates. Instagram for Business is one that is launched for a business purposes tool. Public Relations Officers (PRO) has to be able to formulate the perfect concept, design it into the company or institution's brand, as well as creating captions that strengthen the message implied in the picture of video which will then be posted on their account. There are many entrepreneurs who post pictures and videos without any attractive designs or caption which results in low engagement rate.

The development of Public Relations (PR) is highly affected by the needs and preferences of the users, particularly of competing for private universities. The competition requires support from PR activities in order to bridge the gap with their users. This refers to the four stages in $\mathrm{PR}$ process as stated by Cutlip, Center and Broom (CCB) (2000): 
defining public relations problems. The first stage entails analysis and monitoring of opinions as well as organization policyrelated behaviour. The second stage is planning dan programming. At this stage, the information collected from the first stage is used as the basis of decisions on the public, targets, strategies, actions, and communication goals within the program sett up. The third stage is taking action and communicating. This stage realizes the designed program and communication in order to achieve the aim of the program. The fourth stage is evaluating the program. It involves the assessment and implementation of the program results (Ardianto, 2011). For evaluation, the success of content can be seen from the activities carried out by followers, such as follow, like, comment, mention, geotagging (Bambang Dwi Atmoko, 2012)

With the tight competition taking place among private universities, attractive contents play an important role in narrowing it, Jolly (1996) believes that to qualify as a company implementing a global public relations strategy, it must be able to demonstrate global competitiveness and resources (Oliver, 2008). Student candidates seek information on Instagram. The survey shows that $67 \%$ of Instagram accounts owners are between the age of 18 to 34 years old, who is productive age range (Ii, 2016). If the content solely focuses on broadcast messaging without any interaction, student candidates can divert their attention to another university that provides it. Unfortunately, some private universities hve yet to have a social media team nor the equipment to support content creation. Hence, their contents are monotonous and do not focus on Instagram engagement rate, which functions as the tool to measure the level of success of social media content.

Based on the data, this research aims at further examining the role and the activation of social media in Unisba in regards to information provision and effectiveness for its target students. According to the Head of Public Relations, Unisba is currently maximizing the use of social media as the source of information for the public, particularly during th Covid-19 pandemic. Universitas Islam Bandung is the first private Islamic university in Bandung, which was established in 1958. Unisba's official account@universitasislambandung is managed by Komunikasi Informasi dan Promosi (Kominpro) Unisba. The use of Instagram account @ universitasislambandung covers all of the information on all activities in Unisba. It has around 20.100 followers. Followers are accounts that follow one's social media account (Bhariatta et al., 2019). Unisba currently oversees 34 private universities is a role model. The result of this research can be used as a guide in using and activating Instagram as a communication media and information for all Unisba's sub universities across West Java.

This article is an analysis on Unisba's social media orchestration as a part of Humas Unisba activities. It focuses on Instagram account @ universitasislambandung managed by Humas Unisba. Descriptively, this qualitative analysis identifies content materials, captions, and hashtags. It also assesses the planning of ths, production, andpublication of material as well as engagement as the key factor in the Instagram activation. The goal is for Instagram account @ universitasislambandung to provide its followers and viewers encouragement to continuously stay updated on the information shared in the account.

It is evident that in the Public Relations process, Instagram account @ universitasislambandung is not only 
a virtual display for its users, but its visual performance is optimized by ensuring that the concepts are in line with Unisba's vision and mission. Action is taken after the planning stage, which is evaluated to measure users' response towards the performance and management of Instagram account@ universitasislambandung.

Technology has shifted the PR communication pattern, allowing easier access and interaction between PR and its users. The potential influence of the internet cannot be measured, but there is strategic potential in using the internet as a channel of information, to distribute news, to build a communication channel and as a channel for transactions (Oliver, 2008). The use of social media allows PR to reach its users without any intervention. "New media is a new bridging viewed from time, use, production, and distribution. One prominent characteristic is the interaction between humans with computers and the internet. The model varies ranging from web, blog, online social network, and forum" (Mahendra, 2017). The development of new media has provided options to the youth to express themselves, receiving, or sharing information. "Indonesia is one of the countries with the highest number of Instagram users, 89 percent of them are between the age of 18-34 years accessing IG (Instagram) once a week minimum (Remaja, 2017). In addition to that, "recent surveys show that Instagram is the second most popular platform media with $59 \%$ online users being at the age of 18-29 years old (A. Jackson, 2017)"'(Sakti \& Yulianto, 2013).

The use of social media as a part of orchestration is a communication strategy implemented by PR in order to directly reach its targets. Now, the world of public relations is experiencing a golden age because internet technology has brought practitioners able to reach the target public directly, without intervention from other parties such as editors or journalists in the mass media, who usually act as gatekeepers for communication messages and censorship messages of public relations information for the public (Soemirat \& Ardianto, 2019). The media that can be used are paid media, earned media, and owned media. Paid media is media that incurs a fee (Xie et al., 2018), for example, paid endorsement), sponsored content, mobile advertising, paid influencer and paid search. Earned media is a review on the published party without any fee (Xie et al., 2018), for example, blog review, online interview coverage, vlog unboxing, etc. Owned media is a created media, owned, and managed by corporates, or the relevant party (Dakouan \& Benabdelouahed, 2019, Macnamaraet al. 2016), for example, website or blog of a company, email newsletter, e-magazine, etc (Yoni et al., 2015). Based on the use of media, Unisba possesses several social media accounts, such as Instagram, Facebook, Twitter, YouTube and website. These accounts are then designed to present the institution while promoting engagement with its users (FIGURE 1).

\section{METHODS}

The method used in qualitative research. "According to Strauss and Corbin in Cresswell, J. (1998:24), qualitative research is a type of reserach which produces finding that are not achieved by statistical or quantitative procedures" (Sudrajat \& Moha, 2019). This article is the result of analysis of the first stage which focuses on research object analysis. The findings will be used to identify the orchestration aspects of Humas Unisba social media.

This research is a qualitative analysis at descriptive level that analyzes the look of Unisba's Instagram official account, which includes the contents, 


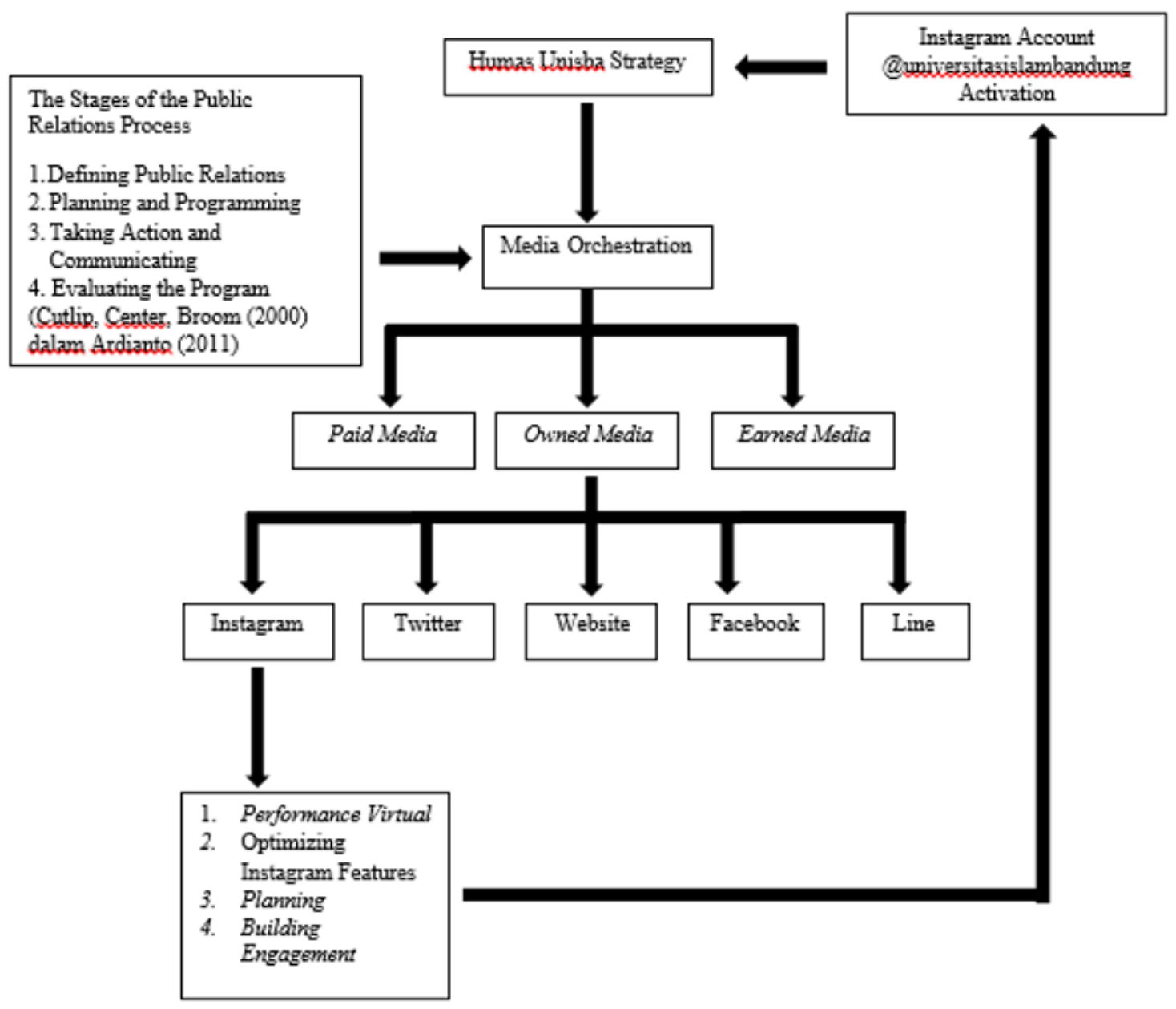

FIGURE 1. Theoritical Framework

material features, and users interactions. Additionally, it also observes the planning stage conducted by the team to analyze the management strategy of Instagram as a part of PR orchestration.

In this research, a purposive sampling technique was used. This means that the sample is drawn or taken refers to the research objectives (Daymon \& Holloway, 2010). The research subject is Kominpro Unisba (Kepala Bagian Humas Unisba, Kepala Seksi Promosi dan Media Sosial, Kepala Seksi Humas dan Protokoler, Kepala Seksi Dokumentasi dan Publikasi) who acts as the manager of Unisba's official account. It aims at examining the activity of Instagram activation as communication and information media. Student candidates and Unisba existing students are the parties that will decide how attractive and useful the account is based on their perspective. Each member of Kominpro Unisba has her/his own role. Concepts and choice of materials are the responsibility of The head of PR and the other sub heads along with their staff. The Head of Promotion and Social Media along with the staff then publish the material using the agreed design, write the caption and hashtag, then monitor the comments. The Head of $\mathrm{PR}$ is in charge of PR policies.

Data are collected through indepth interviews. "Interview is a form of communication between two people, with one seeking information from the other by asking purposeful questions" (Mulyana, 2001). Anin-depth interview is a process of obtaining information for research purposes by means of face- 
to-face question and answer between the interviewer and the respondent or the person being interviewed, with or without using an interview guide where the interviewers and informants are involved in a relatively long social life (Sutopo, 2006).

The next stage is observation. According to Dagun, observation is "a continuous monitoring aiming at gaining knowledge on experience and daily life" (Dagun, 2006). The observation was conducted by monitoring the Instagram account@universitasislambandung and its practice along with literature work conducted by the researcher. "According to Zed (2003), literature work is a series of activities related to the method of literal data, reading, and note-taking, as well as processing research data." (Supriadi, 2017).

\section{RESULTS AND DISCUSSION}

This research describes the process taken by Kominpro Unisba in deciding the contents and materials, the planning, and the effort put into ensuring a high level of customer engagement (TABLE 1). The above components create an attractive orchestration for users benefits. In order to adapt to the habit of the youth who are the targets of Unisba, the use of social media is crucial. The tight competition among universities encourages Unisba to be closer to the millennial by means of social media, especially Instagram, to encourage them to choose Unisba.

\section{The Decision Making Process on Contents and Materials on Instagram account:@universitasislambandung}

Attractive displays along with photos and brief captions are Instagram's competitive edge. "With their background as the social media application that focuses on photo sharing, Instagram possesses a unique characteristic, i.e. landscape photo frame which is similar to Kodak Instamatic and Polaroid. This is different from one with aspect ratio 16.9 which is normally used by cellphone cameras."(Salbino, 2014). Currently, users are in need for information with concise yet clear contents. Instagram happens to be one that offers the needs. The challenge is then for the managers of social media accounts to ensure they produce attractive content

The existence of Instagram has become its own selling point as each photo is expected to look presentable, short videos, and concise yet clear captions. Yadi agrees that Instagram users are segmented to teens. Therefore, the pictures displayed has to be attractive, varied, yet informative (Supriyadi, 2017).

The most important part of Instagram is its content. In regards to the marketing of Instagram, content is equal to the soul. Users compete in creating captivating contents in their accounts for popularity among its followers or potential followers. Contents play an important role as it differentiates one account from the others. Content creation requires careful planning as it greatly affects the result.

According to Ane, the contents displayed on Instagram account @ universitasislambandung currently act as information source for potential students as well as a media for interactions by means of DM (Direct Message). The followers can write their comments which will then be directly replied to by the account administrator. The information shared is not only for potential students, but also for existing ones. For example, IKT payment, graduation related information, etc. News on Unisba can be accessed on its official website, but the excerpts are uploaded on Instagram. The interactive platform is also provided via direct message (DM) or LINE. The findings show that users engagement level is crucial. The bottom line is that information/ clarification sharing, confirmations, 
TABLE 1. Research Findings

\begin{tabular}{|c|c|c|}
\hline No & Point of the Research & Research Findings \\
\hline \multirow[t]{14}{*}{1} & $\begin{array}{l}\text { The Decision Making } \\
\text { Process on Contents and } \\
\text { Materials }\end{array}$ & $\begin{array}{l}\text { Instagram account @universitasislambandung not only } \\
\text { display informational content but also as a medium of } \\
\text { interaction. }\end{array}$ \\
\hline & & $\begin{array}{l}\text { Information shared is not only for potential students, but } \\
\text { also for existing ones }\end{array}$ \\
\hline & & $\begin{array}{l}\text { - News on Unisba can be accessed on its official website, } \\
\text { but the excerpts are uploaded on Instagram. }\end{array}$ \\
\hline & & $\begin{array}{l}\text { - The content should able to provide information on any } \\
\text { activities in the form of photos and conveniently upload } \\
\text { them }\end{array}$ \\
\hline & & $\begin{array}{l}\text { - The choice of contents on Unisba's Instagram account is } \\
\text { in compliance with current programmes. }\end{array}$ \\
\hline & & - $\quad$ Contents are updated daily. \\
\hline & & $\begin{array}{l}\text { - The distinctive feature of the contents on Instagram } \\
\text { account @universitasislambandung is seen from the } \\
\text { daily theme (Thematic Agenda) }\end{array}$ \\
\hline & & $\begin{array}{l}\text { - The contents on @ universitasislambandung is created } \\
\text { based on a designated template with a theme, which is } \\
\text { then uploaded. }\end{array}$ \\
\hline & & $\begin{array}{l}\text { - The template is updated monthly while the grand design } \\
\text { annually. The use of template is based on colours }\end{array}$ \\
\hline & & $\begin{array}{l}\text { - Maximize the role of the Instagram account profile by } \\
\text { adding. bit.ly that is connected to only Line }\end{array}$ \\
\hline & & Content must be uploaded with hashtags. \\
\hline & & $\begin{array}{l}\text { The mandatory hashtags on this account are \#Unisba and } \\
\text { \#universitasislambandung, other hashtags are created in } \\
\text { line with the theme of the programmes. }\end{array}$ \\
\hline & & Captions must use the appropriate language for users \\
\hline & & Unique feeds must be displayed based on themes. \\
\hline 2 & $\begin{array}{l}\text { The Planning Conducted } \\
\text { By Humas Unisba }\end{array}$ & $\begin{array}{l}\text { There are some stages conducted by kominpro team } \\
\text { when uploading information about activities, e.g. data } \\
\text { collection, detailed information, and designing. This is } \\
\text { done by confirming it with related parties. } \\
\text { Some features are used in this account, e.g Instastory, } \\
\text { Instagram TV, Live report. They have the equipment to } \\
\text { produce their own videos, do live reports and more. }\end{array}$ \\
\hline 3 & Online Engagement & $\begin{array}{l}\text { Online engangement is displayed by the number of } \\
\text { viewers who become followers and 'like' the posts, } \\
\text { comment on them, and send a DM } \\
\text { The majority of comments are complimets. All comments } \\
\text { will receive a direct response from the administrators } \\
\text { Evaluation is conducted by monitoring Instagram Insight } \\
\text { and involving external parties }\end{array}$ \\
\hline
\end{tabular}


and questions and answers can directly take place on Instagram or other social media. This is the implementation of the activation of Instagram account @ universitasislambandung as a media for communication and interactions with the users.

"Banyak ya, seperti kegiatankegiatan yang diselenggarakan Unisba, prestasi yang diraih Unisba dan Mahasiswa Unisba, Informasi-informasi penting unisba, dan tentang penerimaan mahasiswa baru informasiinformasi untuk mahasiswa lama seperti pembayaran IKT, Informasi wisuda dll, sama informasi mahasiswa baru, kaya pendaftaran kalo misalnya lagi taaruf. Pokonya informasi-informasi yang harus disampaikan, kalo dulu harus dateng langsung atau Cuma ada di web Unisba aja, sekarang mah di instagram juga bikin informasi itu, walaupun seperti berita-berita unisba lengkapnya sih diliat di web tapi secara garis besar ada di instagram, dan bisa ngobrol juga kan lewat DM anak-anak tuh kalo nanya. Kan kalo di line Cuma ngobrol doang, kalo instagram bisa ngobrol sekalian menyampaikan informasi." (Interview with Ane, The Head of Promotion and Social Media Division, Tuesday, 3 September 2019 at 11.30 AM).

Through Instagram kominpro Unisba is able to provide information on any activities in the form of photos and conveniently upload them. This is deemed to be better than Line as it does not constantly notify the users on broadcasts.

The choice of contents on Unisba's Instagram account is in compliance with current programmes. Contents are updated daily. Contents for incidental activities are created in accordance to the materials of the running program in order to provide information about it by means of photos and captions. On the other hand, the contents for regular activities do not only include photos, but also texts or articles about it that are designed with story lines and noticeable colours. "Contents are not only produced in the form of texts, but also audio, visual, and audio-visual" (Kusuma \& Sugandi, 2019). According to Eki, the content that needs to be uploaded, will be adjusted to the conditions

\section{"Konten-konten akan disesuaikan dengan kondisi pada saat mau upload, kalo yang rutin sih biasanya kan kita udah tau acaranya jadi dari awal menginformasikan kepada publik melalui instagram, tapi kalo keiatan yang engga rutin, misalnya pelatihan atau apa lah kita share fotonya dan dibuat captionnya." (Interview with Eki, the Head of Documentation and Publication Division, Wednesday 4 September 2019 at $1.00 \mathrm{PM}$ )}

The distinctive feature of the contents on Instagram account @ universitasislambandung is seen from the daily theme (TABLE 2). According to the interview with Ane, she said that the contents on@universitasislambandung is created based on a designated template with a theme, which is then uploaded. The template is updated monthly while the grand design annually. The use of a template is based on colours. For example, the one for Unisba's programmes changes colours every month and design every year. What differentiates this is the monthly uploaded feeds, e.g. July is blue and yellow, August is red, turquoise, and white to adhere to the independence month, and September uses bright colours with a shade of yellow. The daily 
TABLE 2. Thematic Agenda

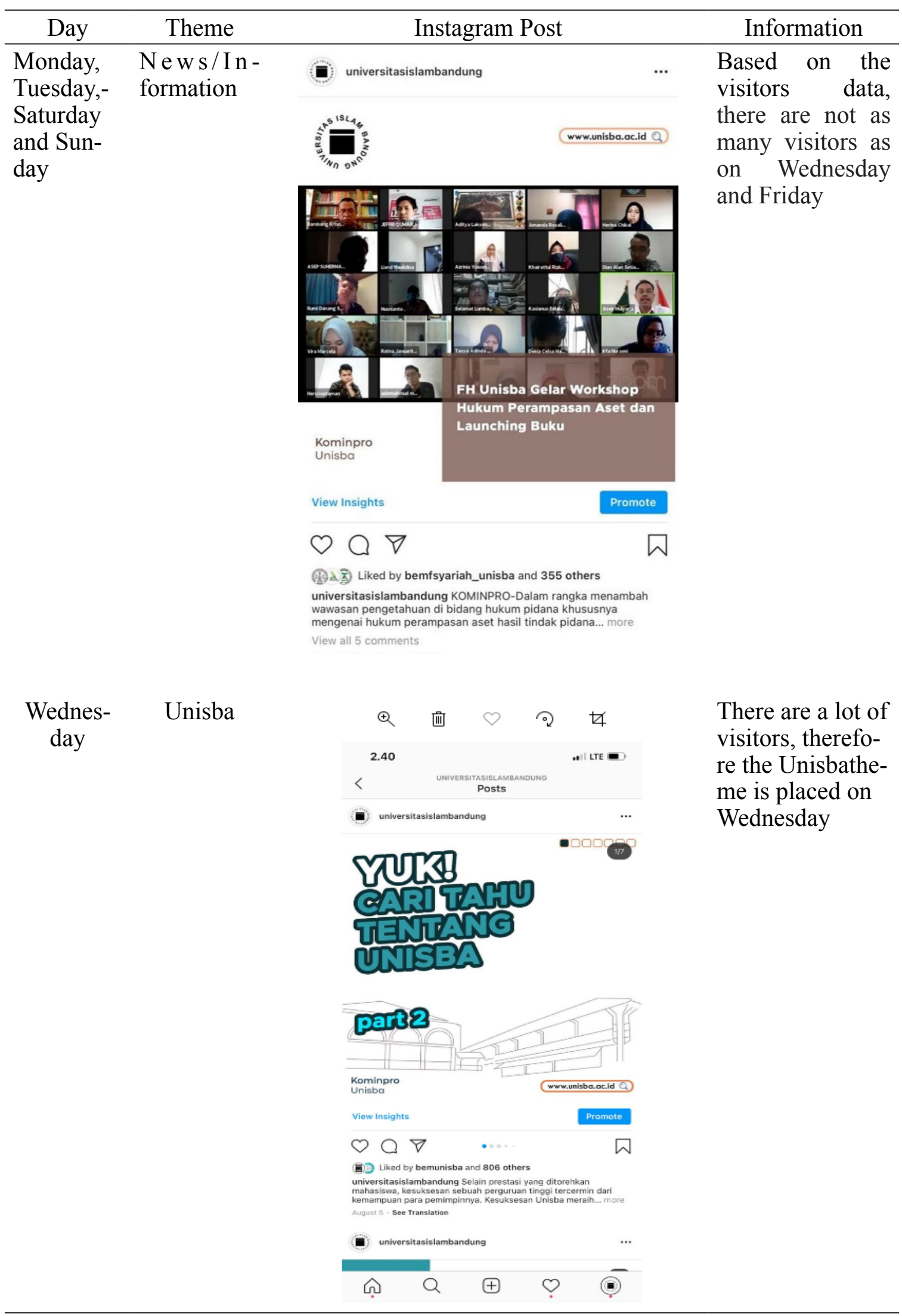


Maya Amalia Oesman Palapah. Instagram Activation as a part of University...

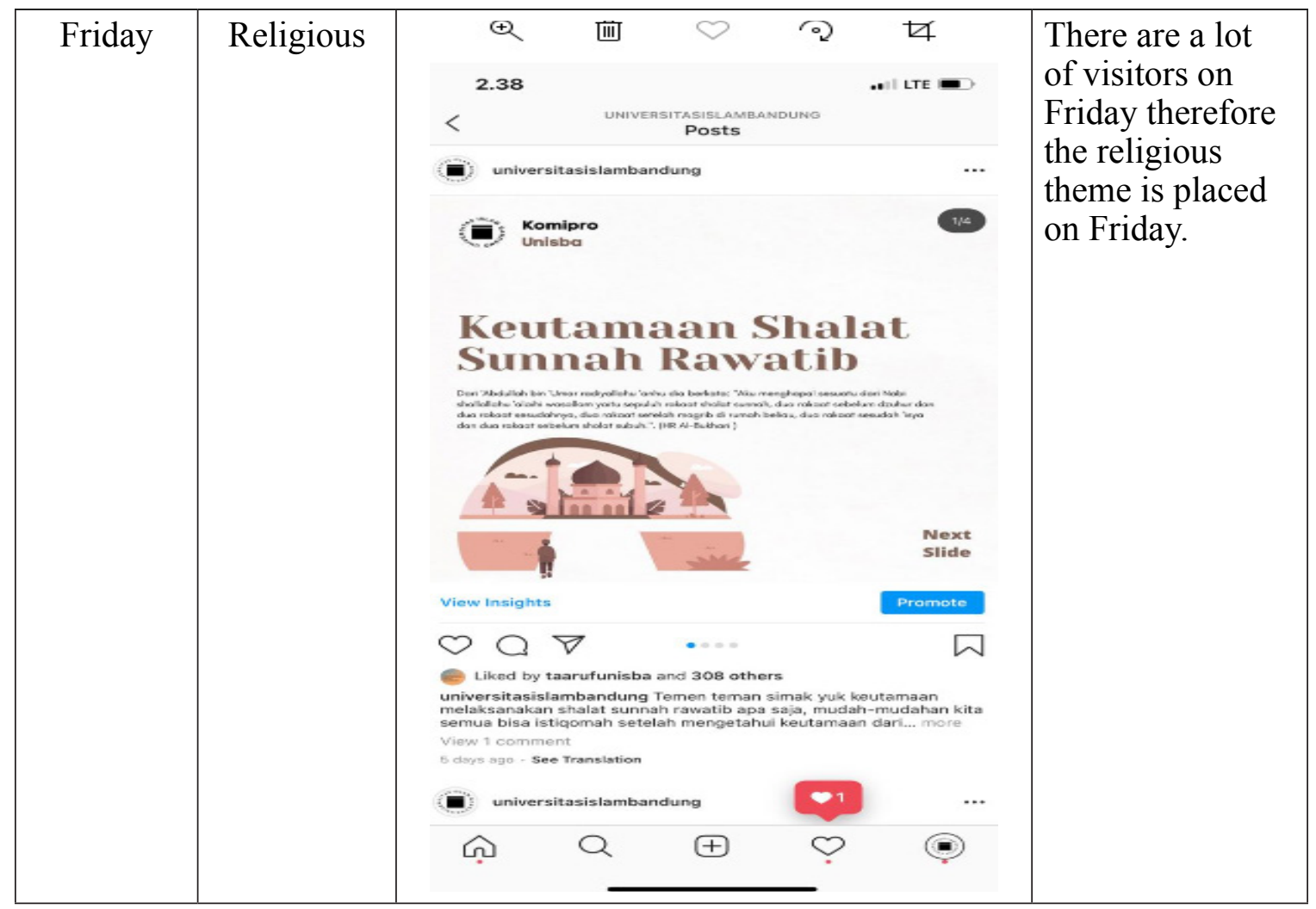

posts change depending on viewers data (TABLE 2 attached).

Other than activities, contents are crucial in the creation of the profile of an Instagram account. Profile picture used as the official logo for Unisba is Ka'bah with a writing that says Universitas Islam Bandung around it. (FIGURE 2). The use of photos is imperative for branding purposes. It has to look professional, therefore, presents itself as a trusted account. Another part of the profile is the use of bit.ly that is connected to Line only. This is confirmed by the admins where the users of Line are mostly university students and high schoolers who are their targets. Based on the results of interviews with students, the admin should use not only Line but also other social media. However, there is a possibility that parents or the public who use other social media, such as WhatsApp, seek information that involves fast responses.

The use of hashtags that are currently trending on Instagram can be done to increase the number of followers. "Hashtag acts by connecting and grouping contents and information that are similar" (Lib \& Prakoso, 2019). Content visibility increases in accordance with the use of hashtags. When hashtags are used for promotional purposes of an educational institution such as Unisba, its students or potential students can easily access information about Unisba using the feature on Instagram. This has been implemented by the administrators when highlighting activities or tagging internal and external institutions involved in their programmes. The mandatory hashtags on this account are \#Unisba and \#universitasislambandung, other hashtags are created in line with the theme of the programmes.

Instagram has engaging visual content features. However, one of the important factor is the caption that comes with the photos. The appropriate caption is a tool for an institution to share their programmes, company profile, achievements, etc. The accompanying sentence enables administrators to 

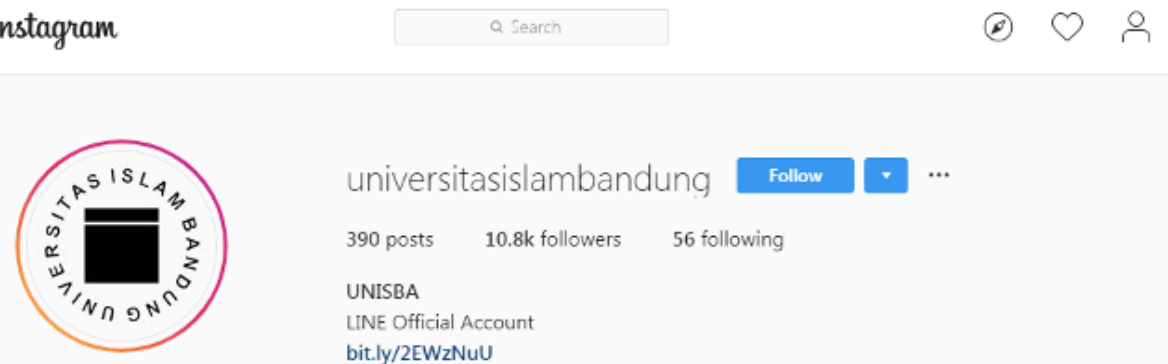

universitasislambandung

Follow

390 posts $\quad 10.8 \mathrm{k}$ followers $\quad 56$ following

UNISBA

LINE Official Account

bit.ly/2EWzNuU

FIGURE 2. Instagram Profile @universitasislambandung

strengthen the description of the pictures, clarifying contexts, and even encouraging a viewer to follow the account. Caption creation is closely related to the language used by the administrators when approaching their target market. There should be a level of consistency in each post. This stage involves consultation with the Head of PR and the team. According to The Head of Humas Unisba, caption written must be based on the existing data and facts because they need to maintain the good image of the institution.

"Caption pasti disesuaikan dengan segmented yang kita tuju dan tetep pada prinsipnya kita harus menyampaikan info yang benar sesuai dengan data dan fakta dan ada. Dan kita harus selektif dalam menggunakan kata-kata karena medsos Unisba merupakan representasi dari lembaga, harus menjaga nama baik lembaga" (Interview with Tresna Wiwitan, The head of Humas Unisba, 11 April 2020 at 7.17 AM)

The language used in captions is casual with non authoritarian design. The language should be appropriate for the youth (FIGURE 3). However, even though the language used refers to the millennial's, it should still consider the norms in the delivery. For example, "jangan lupa hari penutupan registrasi mahasiswa baru yaa." This is supported by Annesia: "a good language style should possess three basis: honesty, manners, and attractiveness." (Annesia, 2018).

There are a number of terminologies used to display visual contents on Instagram, such as post and feeds.

\section{A Liked by rizahernawati and $\mathbf{3 0 8}$ others}

universitasislambandung Temen teman simak yuk

keutamaan melaksanakan shalat sunnah rawatib apa saja, mudah-mudahan kita semua bisa istiqomah setelah mengetahui keutamaan dari shalat sunnah rawatib.

\section{Jumat Mubarak}

\section{Rabi'ul Awal $1442 \mathrm{H}$}

FIGURE 3. Sample caption@universitasislambandung 
A post may include pictures/ videos, caption, geotag, and user tags. While feeds has a collection of pictures or videos. Feed means "a feature that shows notifications about activities done by Instagram users" (Oktaresiyanti, 2019). Unique feeds displayed based on themes, for example through the use of colourful backgrounds and pictures for each display.

Some factors that are the basis of the importance of creating Instagram feeds that are theme based are so that the gallery display is more organized, neat, and attractive so that it encourages viewers to become followers (FIGURE 4). The management and arrangement of photos that are organized will motivate people to stay updated with new posts from the account. Another benefit of a well organized newsfeed on Instagram is the artistic aspect of the account. Common displays are monotonous and may lead to stagnant number of followers. Currently, there is a feature that allows separate displays of parts of a picture that when uploaded they form one whole complete picture.

The planning conducted by Humas Unisba in order to share information through Instagram account (a) universitasislambandung.

Instagram is a social media that is popular among the youth. Instagram is currently used for business, branding, and marketing purposes. We Are Social conducted a survey in 2014, the result showed that $32 \%$ of social media users have an Instagram account. Based on this data, it is safe to say that promotion on social media offers a significant market potential. Instagram has many competitive edge, e.g. ease for marketing by means of catalogues and own website. This requires only a smartphone and internet connection (Giantika, 2019).

Information is the main aim of the use of Instagram, especially when a business instagram is managed profesionally by the company or institution. Therefore, a series of structures stages are required

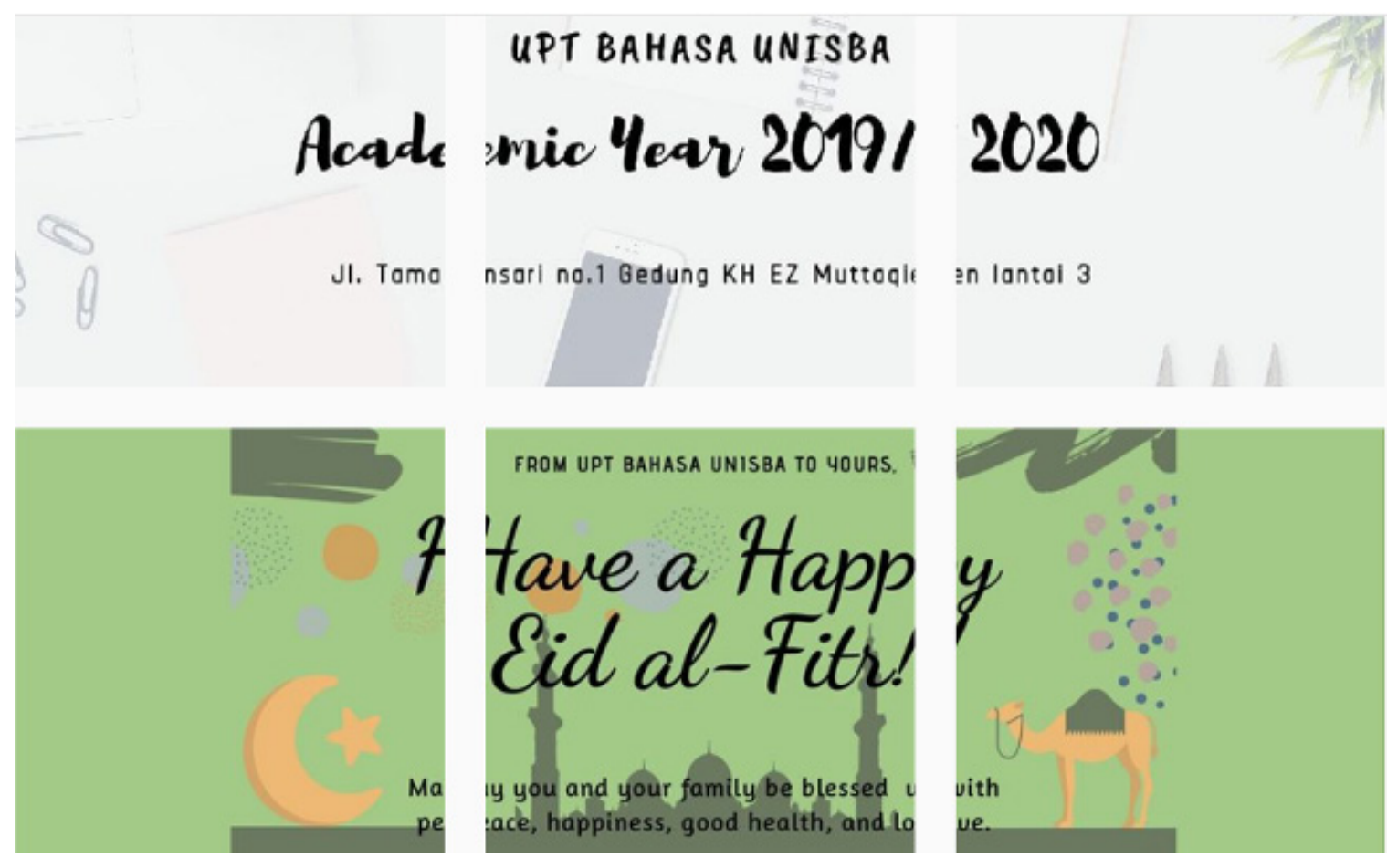

FIGURE 4. Sample feeds 
when posting information on Instagram as it creates an image for the company.

There are some stages conducted by Kominpro team when uploading information about activities, e.g. data collection, detailed information, and designing.

"Pasti ada tahapannya yang pertama kalo untuk kegiatan ada dokumentasi dulu, kemudian kita edit mungkin foto-fotonya, olah juga untuk captionnya, dan kita share. Kalo ada konten-konten kaya misalkan informasi PMB atau pengumuman apapun, didesain dulu kemudian di share" (Interview with Eki, Wednesday, 4 September 2019 at $2.00 \mathrm{PM})$.

At the beginning of the stage, Unisba Kominpro has a designated team that is in charge of documenting each activity in videos or photos. Once the data is collected, photos and videos that are deemed to be presentable are chosen. This is done by the team based on a number of considerations. Photos shared can comprose one or more. Afterwards, a caption is created. The process involves detailed data collection on the activity. Once it is complete, the photo is uploaded onto a template previously designed. The last stage is uploading the information. The information must always be in accordance with the data collected, e.g. payment due date. This is done by confirming it with related parties.

Holiday wishes require the approval from the Head of PR since the design used is new. Once the design is approved, it will then be uploaded. Contents that are a coverage of activities can be uploaded without any approval, e.g. coverage on outstanding students.

The planning does not only focus on themes, production, and material publications on Instagram posts, it also involves other Instagram features, such as Insta Story, Video Live Stream, Instagram $T V$, Highlight Insta Story (Bambang Dwi Atmoko, 2012). Insta story is created daily in the form of repost of that day's posts. Instagram TV is created for certain events, for example new student intake. Live report is conducted for special programmes that are taking place. All of these features can be used with ready to use equipment and human resources. The editing is done by Kominpro.

Engagement as the Key to the Activation of Instagram account a universitasislambandung

Public Relations Officer has to be able to create a systematic plan on technicalities and communication stages. This acts as the basis of the use of social media by Kominpro Unisba. Innovations in the delivery of facts on social media are implemented to increase users engangement. Customer engagement is crucial since the higher the level of engagement, the higher the possibility for a brand or product to be recognized by consumers (Rohadian \& Amir, 2019). A PR practitioner has to evaluate thisto design a strategic set of stages to ensure service excellence. This will greatly affect user engagement.

Evaluation on the use of social media as a platform for knowledge has become prominent in understanding the use of the application (Assegaff, 2017). It is also important to measure the effectiveness of information sharing to allow better strategy, improved services, increasing followers number, improving the relationship with users to grow trust. The evaluation is conducted by analyzing needs and preferences of the viewers and followers.

There are three types of main activities on Instagram, i.e. follow dan unfollow, like and comment, and DM (Direct Message). When a content is 
attractive, it will automatically captive many followers. Online engangement is displayed by the number of viewers who become followers and 'like' the posts, comment on them, and send a DM. Comment can be categorized into compliments, questions, and negative comments. The majority of comments are complimets. All comments will receive a direct response from the administrators. It is important to provide a response since the attention given will increase user engagement. Based on the needs to interact and the timeless nature of social media Kominpro is always ready to answer questions on the account. All of the questions received up to midnight are responded directly and anything above that time are responded the next day.

According to Ane, it is crucial for Kominpro to be familiar with user engagement level of their followers or viewers of@universitasislambandung. High online engangement means high level of needs. In the current digital era, the public seeks information from social media to keep them updated. This particularly is evident among high schoolers. Online engangement via comments or DM provides administrators of the needs of the users.

"Cara mengukur online engagementnyaadadiinstagramnya, karena kita masuknya ke instagram bisnis, jadi bisa dilihat insidenya, kita tuh tiap postingan bisa dilihat, misalnya postingan, di minggu ini ada 39 posting. Dari tanggal 21 agustus sampai 30 agustus itu ada 39 postingan, terus dilihat tuh di likersnya oh banyak ya ternyata yang ngelike kita, terus activity kitanya bisa dilihat, kayanya yang banyak liat tuh di jam segini deh jadi kita kalo upload ya jam segitu, di jam jam pas orang banyak liat instagram kita, profil visit juga kita bisa lihat seberapa banyak yang visit instagram kita, perminggu. Kan kita ada website klick nya berapa, ke emailnya berapa, det direct, discovery (yang nyari unisba), impression (ngeliat doang tapi ga like), rich mah berapa" (Interview with Ane, Tuesday, 3 September 2019 at $11.30 \mathrm{AM})$

One method to find out the result and activities report of an Instagram account is by using a tool on Instagram that is called insight. The data is used as a basis to create a promotional strategy that is better than the previous ones. The team monitors the number of followers visiting their Instagram account weekly. Instagram insight is used to monitor the interaction of followers, e.g. number of visits to@universitasislambandung, number of 'clicks', number of accounts that view the photos/ videos on the account's story. The report published in November 2020 showed that impression and account activity increased.

The evaluation is important to do as the impact of content uploading is significant. According to the Head of Humas Unisba, evaluation is conducted by involving external parties, i.e. PT. Kaze Digital Indonesia, a consultanty agency owned by a subsidiary of ITB in the field of online media and ig data. Once the data is compiled, it provides data that shows users needs in the form of dashboard and ready to use report. The report can be in the form of a sentiment analysis, topic analysis, and any analysis required that are related to online media.

Understanding the importance of the use of Instagram in delivering information to the public in a short period of time has encouraged the administrators of @ universitasislambandung to continuously aim at increasing and analyzing followers needs. They also aim at staying updated with the development of the trends. 
Designs are always new to ensure variety and engagement. One of them is a post that displays Unisba tumbler as a reward to students who are involved in go green.

Effective PR strategy is affected by the ability in combining communicators, messages, media, and appropriate approaches toward the target audience. $\mathrm{PR}$ practitioners refer to this as an orchestration. A post that pleases the public will create positive feelings and the needs for continuous updates. In the context of public relations, such orchestration is required, which entails strategy using the resources in order to increase engagement with the public. In this context, the activation of @ universitasislambandung is a key in the orchestration of Humas Unisba in representing its image to the public.

\section{CONCLUSION}

Content is the important part of Instagram. Currently, the content posted on the@universitasislambandung Instagram account is not only limited to information media aimed at prospective students (high school students), but also as a medium for interaction with them through Direct Message (DM). The selection of content for the Instagram account is adjusted to activities that have taken place, are currently taking place or will take place the following day. Each day the content will be determined by adjusting the conditions at that time.

The planning stages were carried out by Komunikasi Informasi dan Promosi (Kominpro) Unisba team when uploading information about a series of activities, including: collecting data about the activities, detailed information about the activities and making the designs. All posts will go through initial stages in the form of an agreement on the concept that is adjusted to the grand design that has been determined from the beginning. The uniqueness of the content to be broadcasted is that the Kominpro team has made a thematic agenda to be used in advance. Thematic agenda is set based on analysis of existing visitor data. Planning is carefully formulated every year. All the features in Instagram can be done with the complete tools that are owned and the support of the Kominpro team, most of whom have a Bachelor of Communication background

Social media activation must be realized in the form of engagement with the users. At this time, checking the user involvement (engagement) is done in various ways, including analyzing the interests and the needs of visitors and followers; as well as using the online engagement analysis, which can be shown by the number of visitors who then become followers who respond by giving likes, comments and even asking through DM. With more and more online engagements carried out by the visitors, it can be assumed that they really need this account to get information about Unisba. The responsiveness of the Kominpro team in responding has also contributed to increasing online engagement.

In addition, one way to find out about the results and activity reports of an Instagram account is by using one of the tools on Instagram, called Instagram Insight. By knowing this data, it is expected to be the basis for planning a better promotional strategy than before. To optimize information and communication services through the @ universitasislambandung account, the social media performance is carried out not only by using Instagram Insights, but also by collaborating with consultants who can assist in evaluating all Kominpro social media activities, or acting as monitoring media.

\section{REFERENCES}

Afrilia, A. M. (2018). Personal Branding Remaja di Era Digital. Mediator: Jurnal Komunikasi, 11(1), 20-30. 
Maya Amalia Oesman Palapah. Instagram Activation as a part of University...

https://doi.org/10.29313/mediator. v11i1.3626

Annesia, F. Z. (2018). Gaya Bahasa Dan Fungsi Bahasa Caption Pada Akun Gosip Di Instagram.

Ardianto, E. (2011). The Book of Public Relations. Simbiosa Rekatama Media.

Assegaff, S. (2017). Evaluasi Pemanfaatan Media Sosial sebagai Sarana Knowledge Sharing. Jurnal Manajemen Teknologi, 16(3), 271-293. https://doi.org/10.12695/ jmt.2017.16.3.4

Bambang Dwi Atmoko. (2012). Instagram Handbook. InJakarta: PT. TransMedia.

Bhariatta, E. C., Rufaidah, I. N., \& Adnina, M. R. (2019). Jual Beli Followers, Likes, Viewers Di Instagram. El-Qist, 9(1), 1.

Dagun, S. M. (2006). Kamus Besar Ilmu Pengetahuan. : Lembaga Pengkajian Kebudayaan Nusantara.

Daymon,C.,\&Holloway,I.(2010).Qualitative research methods in public relations and marketing communications: Second edition. In Qualitative Research Methods in Public Relations and Marketing Communications: Second Edition. https://doi. org/10.4324/9780203846544

Giantika, G. G. (2019). Pemanfaatan Blog Pribadi Di Instagram Sebagai Media Komunikasi Parenting (Studi Deskriptif Kualitatif Akun Instagram @annisast). Jurnal Komunikasi. https://doi.org/10.31294/jkom. v10i1.4707

Ii, B. A. B. (2016). ke jejaring sosial yang lain. Gambar 2.1 Tampilan aplikasi Instagram dari Web. (. 13-39.

Kusuma, D. F., \& Sugandi, M. S. (2019). Strategi Pemanfaatan Instagram Sebagai Media Komunikasi Pemasaran Digital Yang Dilakukan Oleh Dino Donuts. Jurnal Manajemen Komunikasi, 3(1), 18. https://doi. org/10.24198/jmk.v3i1.12963

Lib, E. D. U., \& Prakoso, A. A. (2019). Penggunaan Hashtag Pada Akun Instagram Perpustakaan Universitas Gadjah Mada. Penggunaan Hashtag Pada Akun Instagram Perpustakaan Universitas Gadjah Mada, 9(1), 54-
66. https://doi.org/10.17509/edulib. v9i1.15504

Mahendra, B. (2017). Eksistensi Sosial Remaja Dalam Instagram (Sebuah Perspektif Komunikasi). Jurnal Visi Komunikasi.

Mulyana, D. (2001). Metodologi Penelitian Kualitatif: Paradigma Baru Ilmu Komunikasi dan Ilmu Sosial Lainnya. In Bandung: PT remaja Rosdakarya.

Oliver, S. (2008). Public Relations Strategy (2nd ed.). Strategic Direction. https://doi.org/10.1108/ sd.2008.05624eae.001

Remaja, D. I. K. (2017). MOTIF PENGGUNAAN MEDIA SOSIAL INSTAGRAM. April, 51-65.

Rohadian, S., \& Amir, M. T. (2019). UPAYA MEMBANGUN CUSTOMER ENGAGEMENT MELALUI MEDIA SOSIAL INSTAGRAM. Journal of Entrepreneurship, Management and Industry (JEMI). https://doi. org/10.36782/jemi.v2i4.1925

Sakti, B. C., \& Yulianto, M. (2013). Penggunaan Media Sosial Instagram Dalam Pembentukan Identitas Diri Remaja. Interaksi-Online.

Salbino, S. (2014). Buku Pintar Gadget Android Untuk Pemula. Kunci Komunikasi.

Soemirat, S., \& Ardianto, E. (2019). DasarDasar Public Relations. Remaja Rosdakarya.

Sudrajat, D., \& Moha, I. (2019). Ragam Penelitian Kualitatif. https://doi. org/10.31227/osf.io/jaxbf

Supriadi, Y. (2017). Komunikasi Politik DPRD Dalam Meningkatkan Peran Legislasi di Kota Bandung. Mediator: Jurnal Komunikasi, 10(1), 25-36. https://doi.org/10.29313/mediator. v10i1.2119

Supriyadi, S. (2017). Community of Practitioners: Solusi Alternatif Berbagi Pengetahuan antar Pustakawan. Lentera Pustaka: Jurnal Kajian Ilmu Perpustakaan, Informasi Dan Kearsipan, 2(2), 83. https://doi. org/10.14710/lenpust.v2i2.13476

Sutopo, H. B. (2006). Metode Penelitian Kualitatif: Teori dan Aplikasinya dalam Penelitian. Jakarta: Bumi 
Aksara.

Xie, Q., Neill, M. S., \& Schauster, E. (2018). Paid, Earned, Shared and Owned Media From the Perspective of Advertising and Public Relations Agencies: Comparing China and the United States. International Journal of Strategic Communication. https://doi. org/10.1080/1553118X.2018.1426002

Yoni, N. L. K. D. P., Pascasrani, N. N., \& Joni, I. D. A. S. (2015). Strategi Komunikasi Melalui Media Sosial Dalam Pembentukan Citra Balebengong Sebagai Media Jurnalisme Warga. E-Journal Medium.

Zakirah, D. M. A. (2018). Mahasiswa dan Instagram (Study Tentang Instagram Sebagai Sarana Membentuk Citra Diri di Kalangan Mahasiswa Universitas
Airlangga). Jurnal S1 Sosiologi FISIP

Universitas Airlangga, 1-21.

\section{ACKNOWLEDGEMENT}

The researcher expressed gratitude to Komunikasi Informasi dan Promosi (Kominpro) Unisba team (Head of Public Relations Unisba, Head of the Promotion and Social Media Section, Head of the Public Relations and Protocol Section, Head of the Documentation and Publication section), Santi Indra Astuti, M.Sc., PhD Cand., and all parties who have assisting the implementation of activities in the research "Instagram Activation as a part of University Public Relations Social Media Orchestration”. 